\title{
Nilai Pesantren Sebagai Dasar Pendidikan Karakter
}

\author{
Whasfi Velasufah \\ Pimpinan Pusat Ikatan Pelajar Putri Nahdlatul Ulama (PP IPPNU) \\ J1. Kramat Raya No.164, Kenari, 005/008, Jakarta Pusat, 10430, Indonesia \\ whsfivel@gmail.com
}

Adib Rifqi Setiawan

$\Lambda$ lobatnio Research Society $(\Lambda \mathrm{RS})$

Jl. Kudus - Colo, Pandak, 001/003, Colo, Kudus, 59353, Indonesia

adibrifqisetiawan@gmail.com

\begin{abstract}
Abstrak
Penulisan esai ini dilatari keprihatinan kami dalam menyaksikan berbagai patologi sosial dan degradasi moral yang terjadi pada generasi penerus bangsa dalam dua dasawarsa terakhir ini. Diharapkan esai ini dapat memberikan setitik sumbangsih dalam upaya menyehatkan kehidupan sosial-keagamaan di negeri ini. Beberapa nilai yang diuraikan menjadi relevan untuk digali dan dikembangkan sebagai bentuk penguatan nilai-nilai luhur bangsa. Nilai-nilai luhur tersebut pada gilirannya memberikan kontribusi untuk mewujudkan Indonesia sebagai negeri yang baik yang dilimpahi maghfirah-Nya (baldatun thayyibatun wa rabbunghafûr).
\end{abstract}

Kata-kata Kunci: Karakter; Nilai; Pendidikan; Pesantren;

\section{A. Pengantar}

Penulisan esai ini dilatari keprihatinan kami dalam menyaksikan berbagai patologi sosial dan degradasi moral yang terjadi pada generasi penerus bangsa dalam dua dasawarsa terakhir ini. Diharapkan esai ini dapat memberikan setitik sumbangsih dalam upaya menyehatkan kehidupan sosial-keagamaan di negeri ini. Dengan cara memperlihatkan berbagai praktik terbaik pendidikan aktual berbasis karakter di dunia pesantren, uraian yang disampaikan dapat dijadikan sumber inspirasi bagi para pembelajar di Tanah Air. Pesantren di sini tidak hanya berfungsi sebagai perspektif, tapi juga merupakan mozaik tersendiri yang di dalamnya memiliki daya tarik, baik dari sosok luarnya, keseharinnya, potensi dirinya, isi pendidikannya, maupun sistem dan metodenya. Tentu saja pesantren dan masyarakat di dalamnya memiliki tata nilai yang dipelihara dan tidak bisa dilepaskan dari subjek reproduksi kader-kader bangsa terpelajar yang memberikan kontribusinya bagi agama, negara, bangsa, dan dunia.

Kekhasan yang dimiliki oleh pesantren tersebut membuatnya bersifat dinamis, terutama dalam merespon perubahan sosial di satu sisi, dan kekuatan yang dimilikinya berupa tradisi dan budaya kehidupan di sisi lain yang secara spesifik tidak dapat dijumpai di lembaga pendidikan lainnya. Pergumulan sosial yang berlangsung di dalam pesantren melahirkan capaian dan prestasi, yang menurut kalangan cerdik-cendekia disebut dengan "tradisionalitas pesantren”. Dengan bertumpu pada konsep-konsep pendidikan, seperti tarbiyah, ta 'lîm, ta'dîb dan tazkiyah, tradisionalitas tersebut menunjukkan adanya kekuatan proses transformasi ilmu dan nilai. Model pendidikan di pesantren inilah dalam banyak hal memiliki keeratan dengan orientasi kesadaran diri, perbaikan perilaku dan penguatan atas perilaku-perilaku yang 
mencerahkan. Daya atau stamina ketiga orientasi pendidikan pesantren tidak ubahnya menjadi ruang spiritualitas tersendiri baik dalam menerjemahkan teks-teks keislaman dalam kehidupan kontemporer maupun melahirkan sikap dan perilaku yang akomodatif, toleran, dan selektif dalam menjumpai modernisasi dengan segala produknya.

Penulisan ini dianggap strategis. Di samping menjadi referensi dalam penguatan pendidikan karakter bangsa dan pelatihan-pelatihan yang terkait di dalamnya, juga menjadi model spesifik pendidikan karakter bangsa yang berbasis pesantren. Latar belakang akademik para penulis buku yang merupakan alumnus pondok pesantren, semakin menguatkan keeratan penulisnya dengan dunia pesantren dan tata nilai yang terus dipelihara.

\section{B. Beberapa Nilai dalam Pesantren}

Pesantren dalam banyak hal secara sosiologis dapat dikategorikan sebagai subkultur dalam masyarakat karena ciri-cirinya yang unik, seperti adanya cara hidup yang dianut, pandangan hidup dan tata nilai yang diikuti secara hierarki kekuasaan tersendiri yang ditaati sepenuhnya. Di kalangan cerdik-cendekia muslim, pesantren telah dikenal sebagai subkultur. Meski dalam kenyataan nya ciri-ciri umum sebagai sebuah subkultur tidak terpenuhi. Dalam penelitian ini, pesantren sebagai sebuah subkultur merujuk pada ciri-ciri minimalis yang antara lain; pesantren merupakan lembaga yang berbeda dari pola kehidupan umum di tengah masyarakat Indonesia, adanya proses pembentukan nilai-nilai tersendiri dengan segala simbolnya dan adanya sistem hierarki yang ditaati (Wahid, 2001, hlm. 135; Wahid, 1995, hlm. 39-60).

Sebagai sebuah sistem kehidupan yang unik, pesantren memiliki pola kehidupan yang berbeda dari pola kehidupan masyarakat pada umumnya. Pola kehidupan di pesantren terbentuk secara alamiah melalui proses penanaman nilai-nilai lengkap dengan simbolsimbolnya, adanya daya tarik ke luar, serta berkembangnya suatu proses pengaruhmempengaruhi dengan ma syarakat di luarnya. Sebagaimana dapat diperlihatkan dari gambaran lahiriahnya, simbol fisik pesantren yang terdiri atas masjid, pondok, dan rumah tinggal kiai, memperlihatkan pola kehidupan yang khas sebagai komunitas beragama yang beranggotakan para santri dengan kiai sebagai pemimpin utamanya (Muhtadi, 2004, hlm. 82).

Dalam perjalanannya, lembaga pesantren selalu mengalami dinamika yang tidak pernah berhenti, sejalan dengan perubahan sosial yang terjadi. Usia pondok pesantren telah mencapai 300-400 tahun yang lalu, ketika untuk kali pertama didirikan oleh Syekh Maulana Malik Ibrahim atau Syekh Maulana Maghribi (w. 12 Rabiul Awwal 822 H/8 April 1419). Beliau mendirikan pondok pesantren di Jawa pada tahun 1399 M untuk menyebarkan Islam (Bull, 1997, hlm. 60).

Sebagai sumbu utama dari dinamika sosial, budaya dan keagamaan masyarakat Islam tradisional, pesantren telah membentuk suatu subkultur yang secara sosio-antropologis bisa dikatakan sebagai masyarakat pesantren. Hal ini diperlihatkan pada dua fungsi utama yang dimiliki pesantren, yakni sebagai lembaga pendidikan yang meniscayakan sebuah sistem pendidikan dan pola belajar-mengajar yang khas ala pesantren. Di samping itu, pesantren berfungsi juga sebagai lembaga dakwah, yang senantiasa melakukan internalisasi nilai-nilai Islam di tengah masyarakat pesantren sendiri dan masyarakat umum. Martin van Bruinessen menyebut tradisi pondok pesantren sebagai salah satu tradisi agung (great tradition) di Indonesia dalam bidang pengajaran Islam di Indonesia yang bertujuan untuk mentransmisikan Islam tradisional (van Bruinessen, 1995, hlm. 17). 
Sebagai lembaga pendidikan yang mempunyai ciri-ciri tersendiri, pesantren memiliki tradisi keilmuan yang berbeda dengan tradisi keilmuan lembaga-lembaga lain. Bila dicermati, ragam keilmuan pesantren dapat diurai menggunakan kerangka al-Ghozālī, yang menyebut bahwa ilmu bisa diklasifikasik menjadi dua macam, yaitu ilmu syar'iyah dan 'aqliyah (intelektual). Ilmu syariah meliputi al-tauhîd, al-lugah, al-tafsîr, al-hadîts, musthalah al-hadîts, al-fiqh, ushûl al-fiqh dan al-akhlâq. Sementara itu ilmu 'aqliyah meliputi matematika, aritmatika, geometri, astronomi, logika, musik, fisika, kimia, kedokteran, metreologi, dan ilmu gaib (alGhozālī, 2005, hlm. 21-38).

Dibandingkan dengan sistem pendidikan lain, pesantren merupakan sebuah kultur yang unik. Keunikannya itu setidaknya ditunjukkan oleh pola kepemimpinan yang berdiri sendiri, literatur universal yang telah dipelihara selama berabad-abad dan sistem nilai yang berbeda terpisah dari sistem nilai yang dianut oleh masyarakat di luar pesantren (Wahid, 1988, hlm. 266). Proses belajar mengajarnya dilakukan melalui struktur, metode dan literatur tradisional, baik berupa pendidikan formal di sekolah manupun madrasah dengan jenjang yang bertingkat, ataupun pemberian pengajaran dengan sistem halaqah dalam bentuk weton atau sorogan. Ciri utama dari pengajaran tradisional ini adalah cara pemberian ajarannya yang ditekankan pada penangkapan harfiah atas suatu kitab.

Meskipun demikian, dalam perkembangan mutakhir, banyak pesantren yang telah membuka sistem pendidikan sekolah atau madrasah yang berarti pola kepemimpinannya melibatkan pihak luar dan literaturnya mengalami perubahan. Jika pondok pesantren tradisional yang semula dikenal sebagai lembaga pendidikan yang tidak mengenal sistem klasikal, tetapi lambat laun mengadopsi model pendidikan klasikal. Di beberapa pondok pesantren, bentukbentuk klasikal dimulai dari tingkat madrasah Ibtidaiyah, Tsanawiyah dan Aliyah. Ada pula menggunakan model Tabaqat Ula, Wustha, dan 'Ulya. Di samping itu, ada pula yang mengambil sistem kemadrasahan dengan pola klasikal berdasarkan kurikulum.

Perubahan-perubahan tersebut dilakukan dalam rangka menyesuaikan kurikulum yang berlaku dan juga penyerapan inspirasi nilai-nilai dari masyarakat guna memenuhi tuntutan zaman dalam waktu yang bersamaan. Ketiga unsur keunikan tersebut masih tetap melekat di pesantren. Hal ini juga tentu menunjukkan inklusivitas dan keluwesan pondok pesantren dalam menyikapi arus perubahan dari luar. Di samping itu mampu menjadi katalisator dalam merespon tantangan dan perubahan yang terjadi di sekitarnya, terutama ketika berhadapan dengan modernisasi sistem pendidikan, baik yang berasal dari sistem pendidikan nasional maupun produk globalisasi.

Dalam konteks Indonesia, pesantren sebagai sub-kultur dipahami bahwa di dalamnya memiliki tatanan nilai serta nilai sentralnya tersendiri. Secara sosiologis, keunikannya sendiri dapat dilihat pada beberapa aspek, yaitu cara hidup yang dianut, pandangan hidup dan tata nilai yang diikuti, serta hierarki kekuasaan internal tersendiri yang ditaati sepenuhnya (Wahid, 1983, hlm. 39). Kepemimpinan pesantren yang diperankan oleh para kiai dan nyai menempatkan keduanya sebagai posisi penting dalam pemeliharaan nilai-nilai. Bahkan perannya dilakukan secara terus menerus dalam kehidupan keseharian berupa transformasi nilai antara para santri dan masyarakat di luar pesantren.

Berbekal penguasaan kitab kuning yang kontekstual dan literatur kontemporer lainnya, masyarakat pesantren melakukan akulturasi budaya lokal dengan tata nilai pesantren. Pesan keagamaan dapat tersampaikan dengan strategi pemanfaatan medium lokalitas. Di samping itu, dalam konteks kekinian banyak dijumpai juga penyelenggaraan pendidikan pesantren 
yang telah memanfaatkan tekonologi media sebagai infrastruktur pendidikan yang penting. Hal ini tentu saja mencerminkan adanya dialog yang berlangsung antara pesantren dan masyarakatnya dengan modernisasi sebagai dampak dari globalisasi.

Walau demikian, potret penting terletak pada pemeliharaan dan transformasi nilai di pesantren itu sendiri. Dua karakter nilai yang dapat diapresiasi misalnya yaitu kemandirian dan cara hidup kolektif. Sebagai lembaga asli produk Nusantara, pesantren menunjukkan ciri khas "gotong royong" yang merupakan bagian dari tradisi masyarakat Indonesia. Pesantren, dengan cara hidupnya yang bersifat kolektif, merupakan salah satu perwujudan semangat dan tradisi gotong royong yang terdapat di masyarakat pedesaan. Nilai-nilai keagamaan seperti al-ukhuwwah (persaudaraan), al-ta'âwun (tolong menolong atau koperasi), al-ittihâd (persatuan), thalab al-ilm (menuntut ilmu), al-ikhlâs (ikhlas), al-jihâd (perjuangan), althâ'ah (patuh kepada Tuhan, Rasul, ulama atau kiai sebagai pewaris Nabi, dan kepada mereka yang diakui sebagai pemimpin), ikut mendukung eksistensi pondok pesantren (Raharjo, 1983, hlm. 9).

Nilai-nilai di atas tentu saja lahir tidaklah dalam kondisi yang tunggal, melainkan melalui proses panjang dan melampaui beberapa tahapan. Nilai-nilai yang dipilih dan ditetapkan menjadi karakter dan identitas peradaban atau kultur tersebut muncul mengalami seleksi alam, di mana kesadaran kolektif akan memilih nilai yang baik, signifikan dan relevan bagi eksistensi peradaban atau kultur itu sendiri. Dalam ungkapan Muhammad Abid al-Jabiri, nilai tersebut disebut dengan "al-qîmah al-markaziyyah" atau dalam bahasa Indonesia disebut dengan nilai sentral (Al-Jabiri, 2001, hlm. 21).

Terdapat banyak faktor yang memengaruhi lahirnya nilai-nilai sentral tersebut, seperti situasi dan kondisi sosial, ekonomi, politik dan sebagainya. Nilai yang menguat kemudian dianggap sebagai nilai sentral, dan nilai-nilai yang kurang mendapatkan momentumnya sebagai nilai cabang. Menguat dan melemahnya nilai yang disebabkan oleh dinamika sosial tersebut juga bisa diakibatkan oleh 'krisis nilai' ('azmah al-qîmah). Misalnya, krisis ekonomi dan menjamurnya korupsi, disebabkan adanya krisis nilai kejujuran atau amanah. Jika krisis kejujuran memunculkan kecurangan dan manipulasi, maka krisis toleransi menimbulkan kekerasan dan anarki, dan begitu seterusnya. Semua nilai itu bagaikan pohon yang dari akar, batang, ranting dan dahannya saling kait-mengait. Karenanya, nilai sentral tak terwujud tanpa adanya nilai-nilai cabang, seperti nilai toleransi yang tidak akan terwujud tanpa nilai penghormatan, penghargaan, rendah hati, kesabaran dan seterusnya.

Selain itu, interaksi antar peradaban atau kultur meniscayakan adanya silang budaya yang berwujud pengayaan sekaligus pergesekan antarnilai yang dibawa setiap peradaban. Nalar etika atau akhlak Islam, misalnya, dibangun berdasarkan nilai berbagai peradaban, seperti khazanah Arab berupa harga diri (al-murû 'ah), khazanah Persia yang bernuansa kepatuhan, khazanah Yunani yang rasional, khazanah sufistik yang bernuansa nihilisme (fanâ), dan khazanah Islami yang berasal dari al-Quran dan hadis (Al-Jabiri, 2001, hlm. 26-27). Nalar etika tersebut diadopsi oleh pesantren melalui khazanah kitab kuning, dan diadaptasikan dengan kebijakan lokal (local wisdom) dan kesadaran kolektif masyarakat Nusantara. Naik turunnya suatu nilai yang diakibatkan dari dinamika sosial dan interaksi antar peradaban tercermin dalam nilai-nilai pesantren yang bersifat dinamis dari masa ke masa.

Dalam konteks sejarah Indonesia, pesantren merupakan lembaga pendidikan dan sekaligus menjadi pusat perubahan masyarakat melalui kegiatan penyebaran agama, terutama era prakolonial. Demikian halnya, ketika memasuki era koloniali sasi bangsa-bangsa Eropa yang 
menguasai daerah-daerah di Nusantara, pesantren menjadi pusat perlawanan terhadap kekuasaan penjajah. Potret sejarah lainnya dapat disimak misalnya, jika di masa 1959-1965 pesantren disebut sebagai "alat revolusi", maka sesudah itu hingga zaman Orde Baru pesantren dianggap sebagai "potensi pembangunan" (Rahardjo, 1983, hlm. 10). Periodesasi sejarah pesantren ini memperlihatkan peran pesantren dalam memelihara dan memperjuangkan nilai cinta Tanah Air. Dalam istilah modern, nilai ini seringkali diartikan dengan nasionalisme. Nilai yang dikembangkan pesantren dalam merespon dinamika sosial kebangsaan, membuktikan bahwa ia tidak mengasingkan diri dari persoalan di luar dirinya.

Nilai-nilai lainnya yang dikembangkan pesantren yaitu kemandirian, kerjasama, cinta Tanah Air, kejujuran, kasih-sayang, penghargaan, kesungguhan, rendah hati, tanggung jawab, kepedulian, kesabaran, kedamaian, musyawarah, toleransi dan kesetaraan. Pesantren kemudian dipandang berhasil membentuk karakter positif pada para siswa didik (santri) karena menerapkan pendidikan yang holistik, berupa tarbiyah (pembelajaran) yang meliputi ta 'lîm (pengajaran) dan ta'dîb (pembentukan karakter atau pendisiplinan).

\section{Penutup}

Beberapa nilai yang telah diuraikan di atas menjadi relevan untuk digali dan dikembangkan sebagai bentuk penguatan nilai-nilai luhur bangsa. Beberapa nilai pesantren yang mulai terabaikan, layak dihidupkan kembali untuk khalayak luas. Misalnya, nilai gotong royong di tengah masyarakat yang kini cenderung materialistis, atau nilai toleransi di tengah masyarakat yang kini cenderung alergi dan anti terhadap kelompok yang berbeda. Nilai-nilai luhur tersebut pada gilirannya memberikan kontribusi untuk mewujudkan Indonesia sebagai negeri yang baik yang dilimpahi maghfirah-Nya (baldatun thayyibatun wa rabbunghafûr).

Pendidikan karakter yang berbasis nilai-nilai kepesantrenan memiliki teori yang memadai tentang makna karakter yang baik itu dan cara menanamkan nilai itu. Pembentukan karakter yang berbasis nilai-nilai kepesantrenan dipahami secara luas agar mencakup aspek kognitif, afektif dan perilaku moralitas/psikomotorik. Dalam bahasa agama, karakter yang baik yang berbasis nilai-nilai itu terdiri dari "mengetahui apa itu baik dan buruk" (amar ma'ruf nahi munkar), "menginginkan yang baik", (himmah) dan "melakukan yang baik" (amal shâlih).

Agar nilai-nilai ini dapat diterapkan, maka lembaga pendidikan seperti universitas/institut, madrasah, sekolah atau pesantren harus membantu anak didik memahami nilai-nilai inti, mengadopsi atau mempraktikkannya untuk diri mereka sendiri, dan kemudian bertindak dalam kehidupan mereka sendiri. Dalam pendidikan di pesantren disebut ta'lîm (pengajaran) dan $t a$ 'dîb (pembiasaan dengan kesadaran). Orang bisa menjadi sangat cerdas tentang hal-hal yang baik dan buruk untuk kehidupannya, namun dapat tetap memilih yang salah. Contoh paling sederhana adalah tentang cara membuang sampah. Pendidikan moral tidak hanya mengutamakan aspek kognitif dan pengembangan intelektual, tapi juga membutuhkan dimensi emosional/spiritual yang berfungsi sebagai jembatan antara penilaian dan tindakan. Sisi emosional/spiritual mencakup setidaknya kualitas-kualitas nurani (merasa kewajiban untuk melakukan untuk menjadi benar), harga diri, empati, mencintai, pengendalian diri dan kerendahan hati.

Pembentukan karakter mengacu pada tiga kualitas moral, yaitu: kompetensi (keterampilan seperti mendengarkan, berkomunikasi dan bekerja sama), kehendak atau keinginan yang memobilisasi penilaian kita dan energi, dan kebiasaan moral (sebuah disposisi batin yang dapat diandalkan untuk merespon situasi dalam cara yang secara moral baik). Oleh karena 
itu, pendidikan karakter jauh lebih kompleks daripada mengajar matematika atau membaca. Ia meniscayakan pengembangan kepribadian serta pengembangan keterampilan. Hal ini setidaknya merujuk pada adanya tiga unsur pokok dalam pembentukan karakter yaitu mengetahui kebaikan (knowing the good), mencintai kebaikan (loving the good), dan melakukan kebaikan (doing the good). Dalam pendidikan karakter, kebaikan itu seringkali dirangkum dalam sederet sifat-sifat baik. Dengan demikian maka pendidikan karakter adalah sebuah upaya untuk membimbing perilaku manusia menuju standar-standar baku tentang sifat-sifat baik. Upaya ini juga memberi jalan untuk menghargai persepsi dan nilai-nilai pribadi yang ditampilkan di sekolah. Fokus pendidikan karakter adalah pada tujuan-tujuan etika, tetapi praktiknya meliputi penguatan kecakapan-kecakapan yang penting yang mencakup perkembangan sosial siswa.

Dalam pelaksanaan pembelajarannya, dapat diterapkan metode pendidikan berbasis pengalaman (experiential learning). Metode ini dipilih agar seorang siswa/santri dapat menghidupkan sebuah nilai dan pada akhirnya memiliki karakter yang baik, maka mereka tidak hanya perlu diberi tahu tentang nilai itu, tetapi harus diajak mengalami dan berefleksi.

Experiential learning adalah suatu metode pembelajaran yang mengaktifkan pembelajar untuk membangun pengetahuan dan keterampilan serta nilai-nilai juga sikap melalui pengalamannya secara langsung. Karena itu, metode ini akan bermakna tatkala pembelajar berperan serta dalam melakukan kegiatan. Setelah itu, mereka memandang kritis kegiatan tersebut. Kemudian, mereka mendapatkan pemahaman serta menuangkannya dalam bentuk lisan atau tulisan sesuai dengan tujuan pembelajaran. Dalam hal ini, experiential learning menggunakan pengalaman sebagai katalisator untuk menolong pembelajar mengembangkan kapasitas dan kemampuannya dalam proses pembelajaran.

Pada experiential learning, langkah menantang bagi guru adalah memikirkan atau merancang aktivitas pengalaman belajar seperti apa yang harus terjadi pada diri peserta, baik individu maupun kelompok. Kegiatan pembelajaran harus (fardhu 'ayn) berfokus pada peserta belajar (student-centered learning). Dengan demikian, apa yang harus kita lakukan, apa yang harus mereka lakukan, apa yang harus kita katakan atau sampaikan harus sedetail mungkin kita rancang dengan baik. Begitu pula dengan media dan alat bantu pembelajaran lain yang dibutuhkan juga harus benar-benar telah tersedia dan siap untuk digunakan.

Metode experiential learning tidak hanya memberikan wawasan pengetahuan konsep-konsep saja, namun juga memberikan pengalaman nyata yang akan membangun keterampilan melalui penugasan-penugasan nyata. Selanjutnya, metode ini akan mengakomodasi dan memberikan proses umpan balik serta evaluasi antara hasil penerapan dengan apa yang seharusnya dilakukan.

Di antara kegiatan pembelajaran dalam metode experiential learning yaitu mendengarkan musik yang terbukti secara empiris dapat meningkatkan kecerdasan karena iramanya menenangkan pikiran yang merupakan pusat pengendalian tubuh (Rakhmat, 2010, hlm. 214). Penelitian menunjukkan bahwa musik dapat membuat anak-anak lebih tenang, dan karena itu, lebih cerdas. Minat terhadap musik sebagai stimulan otak berasal dari pengamatan pada bayibayi prematur yang berkembang lebih baik ketika diperdengarkan kepadanya musik klasik. Penelitian di sekolah telah menunjukkan bahwa perhatian dan prestasi murid meningkat ketika mendengarkan musik klasik sebagai musik latarbelakang. Para ilmuan musik berteori bahwa musik 'mengorganisaikan' pola-pola neuron di seluruh otak, terutama pola-pola yang 
berkaitan dengan pemikiran kreatif. Para dokter berteori bahwa musik mempunyai efek menenangkan dan merangsang keluarnya hormon endorfin.

Beberapa kegiatanyang dapat diterapkan dalam pembelajaran antara lain:

1) Membaca deskripsi sebuah nilai. Peserta didik diajak untuk membaca arti sebuah nilai tertentu;

2) Bermain peran. Peserta didik bermain peran secara individu, berpasangan, maupun berkelompok;

3) Bernyanyi. Peserta didik diajak untuk menyanyikan lagu yang mengandung nilai-nilai yang hendak dihidupkan;

4) Berbagi refleksi. Peserta didik merefleksikan situasi tertentu yang dihadapi, menuliskannya, dan membagikannya kepada peserta didik lain;

5) Curah pendapat. Peserta didik saling memberikan pandangan terhadap kasus-kasus tertentu, dengan menuliskannya pada metaplan dan menyampaikannya dalam sesi diskusi;

6) Membaca teks kitab kuning. Peserta didik membaca teks kitab kuning dan diajak membuat terjemahan dan analisis kata dan tata bahasa;

7) Membaca puisi dan artikel. Peserta didik membaca puisi dan artikel atau kisah tentang nilai;

8) Berkarya kreatif. Peserta didik diajak untuk menulis syair, puisi, ataupun membuat gambar, pamflet dan karya kreatif lainnya terkait dengan nilai-nilai yang hendak dihidupkan;

9) Berbagi pengalaman. Peserta didik diajak untuk berbagi pengalaman nyata terkait dengan menghidupkan nilai dalam kehidupan pribadi mereka

Dengan mempertimbangkan uraian yang disampaikan, esai ini diharapkan dapat diterima di kalangan pesantren dan masyarakat. Terlebih penulisannya sangat memerhatikan keakraban pendekatan kebahasaan, tema dan psikologi masyarakat sasaran. Namun demikian, dari aspek penyusunan dan pemaparan, esai ini dikemas dengan pemaparan yang bisa diterima oleh berbagai kalangan, karena buku ini diperuntukkan bagi komunitas pesantren sekaligus nonpesantren. Esai ini tidak hanya difokuskan pada 'santri/siswa sebagai bagian dari pesantren/sekolah', tetapi juga pada 'santri/siswa sebagai bagian dari masyarakat' menghidupkan nilai di masyarakat. Sebuah proses transformasi nilai dari pesantren/sekolah ke masyarakat umum. Karena itu, kami tidak menulis terlalu normatif, melainkan praktis dan disampaikan dengan bahasa yang jelas dan yang lebih 'mengajak', serta yang bisa menantang pola pikir para santri/pelajar. Pesan-pesan yang disajikannya bisa sampai kepada para santri dan non-santri sehingga bisa menginspirasi kesadaran mereka.

\section{Referensi}

al-Ghozālī, Abū Ḥāmid Muḥammad. (2005). Ihyya 'ulumū al-dīn. Beirut: Dār Ibn al-Ḥazm. Bull, Ronald Alan Lukens. (1997). A Peacceful Jihad: Javanese Education and Religion Identity Construction. Michigan: Arizona State University.

Muhammad Abid al-Jabiri. (2001). al-'Aqlu al-Akhlâqîy al- 'Arobiy. Beirut: Markaz Dirasat al-Wahdah al-'Arabiyah.

Muhtadi, Asep Saeful. (2004). Komunikasi Politik Nahdlatul Ulama Pergulatan Pemikiran Politik Radikal dan Akomodatif. Jakarta: LP3ES.

Rahardjo, M. Dawam. (1983). Pesantren dan Pembaharuan. Jurnal LP3ES. Jakarta: LP3ES. Rakhmat, Jalaluddin. (2010). Belajar Cerdas: Belajar Berbasis Otak. Bandung: Kaifa Learning. 
van Bruinessen, Martin. (1995). Kitab Kuning: Pesantren dan Tarekat. Bandung: Mizan. Wahid, Abdurrahman. (1983). Pesantren Sebagai Subkultur. Jurnal Pesantren dan Pembaharuan. Jakarta: LP3ES.

Wahid, Abdurrahman. (1988). Prospek Pesantren Sebagai Lembaga Pendidikan. Dalam Muntaha Azhari (peny.) \& Sonhaji Saleh (penj.), Dinamika Pesantren: Kumpulan Makalah Seminar Internasional "The Role of Pesantren in Community Development in Indonesia. Jakarta: P3M.

Wahid, Abdurrahman. (1995). Pesantren sebagai Subkultur. Dalam Dawan Raharjo (peny.), Pesantren dan Pembaruan. Jakarta: LP3ES.

Wahid, Abdurrahman. (2001). Pergulatan Agama, Negara dan Kebudayaan. Jakarta: Desantara. 